\title{
Comparison of observed and modeled cloud-free longwave downward radiation (2010-2016) at the high mountain BSRN Izaña station
}

\author{
Rosa Delia García ${ }^{1,2,3}$, Africa Barreto ${ }^{4,2,3}$, Emilio Cuevas ${ }^{2}$, Julian Gröbner ${ }^{5}$, Omaira Elena García ${ }^{2}$, \\ Angel Gómez-Peláez ${ }^{2, a}$, Pedro Miguel Romero-Campos ${ }^{2}$, Alberto Redondas $^{2}$, Victoria Eugenia Cachorro ${ }^{3}$, and \\ Ramon $\operatorname{Ramos}^{2}$ \\ ${ }^{1}$ Air Liquide España, Delegación Canarias, Candelaria, 38509, Spain \\ ${ }^{2}$ Izaña Atmospheric Research Center (IARC), State Meteorological Agency (AEMET), Santa Cruz de Tenerife, Spain \\ ${ }^{3}$ Atmospheric Optics Group, Valladolid University, Valladolid, Spain \\ ${ }^{4}$ Cimel Electronique, Paris, France \\ ${ }^{5}$ Physikalisch-Meteorologisches Observatorium Davos, World Radiation Center (PMOD/WRC), Davos, Switzerland \\ ${ }^{a}$ now at: Meteorological State Agency of Spain (AEMET), Delegation in Asturias, Oviedo, Spain
}

Correspondence: Emilio Cuevas (ecuevasa@aemet.es)

Received: 29 November 2017 - Discussion started: 16 January 2018

Revised: 26 March 2018 - Accepted: 29 May 2018 - Published: 12 June 2018

\begin{abstract}
A 7-year (2010-2016) comparison study between measured and simulated longwave downward radiation (LDR) under cloud-free conditions was performed at the Izaña Atmospheric Observatory (IZO, Spain). This analysis encompasses a total of 2062 cases distributed approximately evenly between day and night. Results show an excellent agreement between Baseline Surface Radiation Network (BSRN) measurements and simulations with libRadtran V2.0.1 and MODerate resolution atmospheric TRANsmission model (MODTRAN) V6 radiative transfer models (RTMs). Mean bias (simulated - measured) of $<1.1 \%$ and root mean square of the bias (RMS) of $<1 \%$ are within the instrumental error ( $2 \%)$. These results highlight the good agreement between the two RTMs, proving to be useful tools for the quality control of LDR observations and for detecting temporal drifts in field instruments. The standard deviations of the residuals, associated with the RTM input parameters uncertainties are rather small, 0.47 and $0.49 \%$ for libRadtran and MODTRAN, respectively, at daytime, and 0.49 to $0.51 \%$ at night-time. For precipitable water vapor (PWV) $>10 \mathrm{~mm}$, the observed night-time difference between models and measurements is $+5 \mathrm{~W} \mathrm{~m}^{-2}$ indicating a scale change of the World Infrared Standard Group of Pyrgeometers (WISG), which serves as reference for atmospheric longwave radiation measurements. Preliminary results suggest a possible
\end{abstract}

impact of dust aerosol on infrared radiation during daytime that might not be correctly parametrized by the models, resulting in a slight underestimation of the modeled LDR, of about $-3 \mathrm{~W} \mathrm{~m}^{-2}$, for relatively high aerosol optical depth $(\mathrm{AOD}>0.20)$.

\section{Introduction}

Longwave downward radiation (LDR) at the Earth's surface is a key component in land-atmosphere interaction processes, and is crucial in surface energy budget and global climate change, because the changes in the LDR values may be related to changes in cloud cover, cloud type, water vapor, temperature and the increase of anthropogenic greenhouse gas concentrations in the atmosphere (Wild et al., 1997; Marty et al., 2003; Iacono et al., 2008; Philipona et al., 2012; Wild et al., 2013; Wang and Dickinson, 2013; Wild et al., 2015). Thus, LDR measurements and simulations are needed to understand the processes involved in the changes on the LDR sources and levels, and their possible relationships with the sources of climate change (Dutton, 1993; Wild et al., 2001). 
Atmospheric longwave irradiance measurements are usually performed with hemispherical receivers on flat horizontal surfaces. The LDR is mainly measured with pyrgeometers, with the Eppley Precision Infrared Radiometer (PIR), EKO MS-201 Precision Pyrgeometer and Kipp \& Zonen $\mathrm{CG}(\mathrm{R})$ series being the most commonly used (McArthur, 2005). These latter pyrgeometers have been designed for LDR measurements with high reliability and accuracy. The estimated uncertainty for LDR instantaneous values, indicated by the Baseline Surface Radiation Network (BSRN) in 2004, is $3 \mathrm{~W} \mathrm{~m}^{-2}$ (2\%; McArthur, 2005). These values account for calibration uncertainties and are estimated from standard deviation of the calibration coefficients. The Baseline Surface Radiation Network (BSRN) accuracy target for LDR is $\pm 2 \mathrm{~W} \mathrm{~m}^{-2}$, and the average observed LDR change from 24 BSRN sites since the early 1990s has been $+2 \mathrm{~W} \mathrm{~m}^{-2}$ decade $^{-1}$ (Wild, 2017) as a result of the increasing greenhouse effects.

At the beginning of the 20th century, several methods and equations were developed to estimate LDR when or where no measurements were available. The first parameterization of the LDR was developed by Ångström (Ångström, 1918), who developed an empirical relationship between cloud-free emissivity and water vapor pressure at the surface. Following the pioneer work of Ångström, several authors (e.g., Brunt, 1932; Swinbank, 1963; Idso and Jackson, 1969; Brutsaert, 1975; Prata, 1996) proposed diverse relationships capable of simulating LDR based on relationships between LDR, vapor pressure, temperature and the Stefan-Boltzmann constant, since the theoretical basis of this parameterization is the assumption that the atmosphere behaves as a grey body:

$\mathrm{LDR}=\epsilon(T, e) \sigma T^{4}$.

In this equation $\epsilon(T, e)$ is the cloud-free atmospheric emissivity, $T$ and $e$ are the air temperature and the water vapor pressure measured at the surface, respectively, and $\sigma$ is the Stefan-Boltzmann constant $\left(5.67 \times 10^{-8} \mathrm{~W} \mathrm{~m}^{-2} \mathrm{~K}^{-4}\right)$. The abovementioned parameterizations show uncertainties ranging from 9 to $15 \%$ in low altitude sites while at high altitude sites the LDR estimations present uncertainties ranging from 12 to $21 \%$. More recently, Iziomon et al. (2003) presented an improved parameterization that reduces the uncertainties to $6 \%$ for lowland sites and $7 \%$ for mountain sites for all-sky conditions. Ruckstuhl et al. (2007) showed that the monthly mean LDR can be effectively modeled from specific humidity or water vapor obtaining differences $<5 \%$. Dupont et al. (2008) presented a more sophisticated parameterization based on the vertical profiles of temperature and humidity obtaining uncertainties of $\sim 5 \mathrm{~W} \mathrm{~m}^{-2}$ for cloud-free conditions, for both daytime and night-time.

The need to provide more accurate LDR estimates from models to improve climate forecasting led to the introduction of radiative transfer models (RTMs) adapted or developed to simulate such LDRs. There exist several studies in the literature aiming to compare measured and simulated LDR (Mor- crette, 2002; Dürr et al., 2005; Marty et al., 2003; Long and Turner, 2008; Wacker et al., 2011; Viúdez-Mora et al., 2009, 2015). The key point in these studies is the use of data from radio soundings launched at the measurement site which provide vertical profiles of humidity, pressure and temperature as model inputs.

An intercomparison performed by Schweizer and Gautier (1995) with the LOW-resolution TRANSmission (LOWTRAN) model under cloud-free conditions showed that the model simulations generally exceed measured LDR values with a bias of $-0.7 \pm 11 \mathrm{~W} \mathrm{~m}^{-2}$ and a root mean square error (RMSE) of $10.6 \mathrm{~W} \mathrm{~m}^{-2}$ ( $4 \%$ of the measured values). In a similar study, Viúdez-Mora et al. (2009) compared LDR measurements and simulations, under cloud-free conditions, with Santa Barbara Disort Atmospheric Radiative Transfer (SBDART; Ricchiazzi et al., 1998) at two different sites, Payerne (Switzerland) and Gerona (Spain), obtaining differences of $-2.7 \pm 3.4$ and $0.3 \pm 9.4 \mathrm{~W} \mathrm{~m}^{-2}$, respectively. Dürr et al. (2005) found good agreement between LDR measurements and simulations with the MODerate resolution atmospheric TRANsmission model (MODTRAN; Berk et al., 2000), with values of +1.5 and $-3.2 \mathrm{~W} \mathrm{~m}^{-2}$ for night-time (274 cases) and daytime (94 cases), respectively, at Payerne station.

The main goal of this work is to compare BSRN LDR measurements with simulations made with two complex models using observed and modeled data from a relatively long period (between 2010 and 2016). The Izaña Atmospheric Observatory (IZO, http://izana.aemet.es, last access: 28 November 2017) is an optimal station to carry out this study, because all the model input parameters (PWV, precipitable water vapor; AOD, aerosol optical depth; total ozone; in situ $\mathrm{N}_{2} \mathrm{O}$; in situ $\mathrm{CO}_{2} ; \mathrm{CO}_{2}$ profiles; meteorological radiosondes) are measured at the station. This work is divided into six sections. Section 2 describes the main characteristics of the IZO test site. In Sect. 3 the technical description of instruments and measurements performed at IZO and the method used for the detection of cloud-free days are shown. Section 4 introduces the libRadtran and MODTRAN models and the model input parameters used in this work as well as a theoretical uncertainty assessment of the simulations made with both models. The results of the comparison and the temporal stability of the LDR observations are shown in Sect. 5, and finally, the summary and conclusions are given in Sect. 6 .

\section{Site description}

The Izaña Atmospheric Observatory is a high-mountain observatory located in Tenerife (Canary Islands, Spain, $28.3^{\circ} \mathrm{N}$, $16.5^{\circ} \mathrm{W}, 2373 \mathrm{~m}$ a.s.1.). IZO is managed by the Izaña Atmospheric Research Center (IARC) which forms part of the Meteorological State Agency of Spain (AEMET). Its location in the Atlantic Ocean and above a stable inversion layer, typical for subtropical regions, provides clean air and clear sky conditions most of the year, offering ex- 

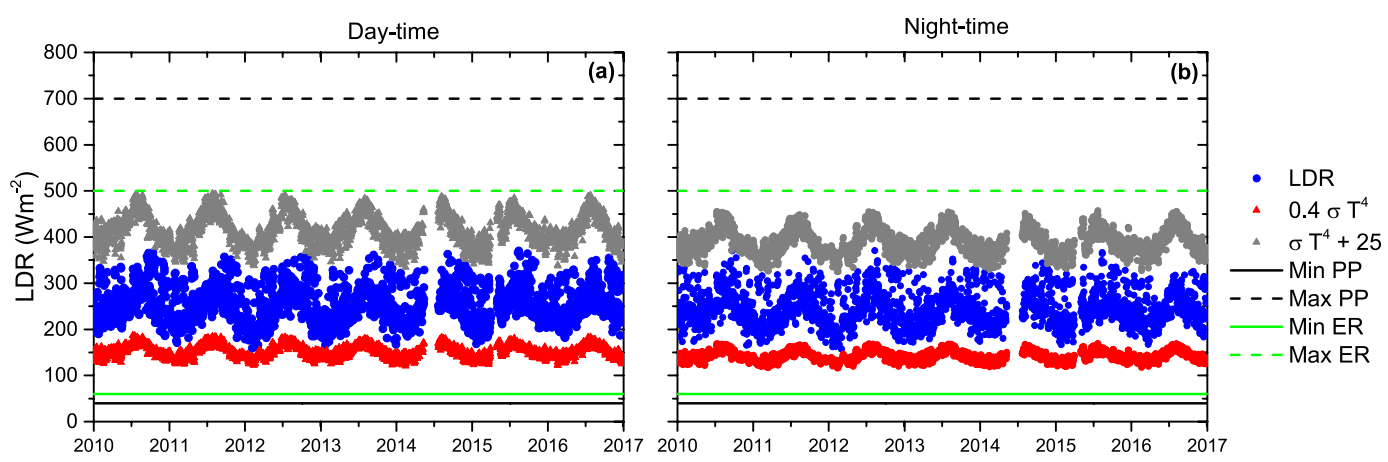

Figure 1. The LDR time series obtained at (a) daytime and (b) night-time with a CG(R)4 pyrgeometer between 2010 and 2016 at IZO BSRN (blue dots). The black and green lines represent the physically possible (Min PP, Max PP) and extremely rare limits (Min ER, Max ER), respectively; the grey and red dots represent the upper $\left(\sigma T^{4}+25\right)$ and lower $\left(0.4 \sigma T^{4}\right)$ limits, respectively, where $\sigma$ is Stefan-Boltzmann constant $\left(5.67 \times 10^{-8} \mathrm{~W} \mathrm{~m}^{-2} \mathrm{~K}^{-4}\right)$ and $T$ is the air temperature in $\mathrm{K}$.

cellent conditions for calibration and validation activities. In 1984, IZO became a member of the World Meteorological Organization (WMO) Background Atmospheric Pollution Monitoring Network (BAPMoN) and in 1989 it became a Global Atmosphere Watch (GAW) station. In addition, it has been actively contributing to international radiation networks and databases such as NDACC (Network for the Detection of Atmospheric Composition Change; http: //www.ndsc.ncep.noaa.gov/, last access: 25 November 2017) since 1999, AERONET (Aerosol Robotic Network; http: //aeronet.gsfc.nasa.gov/, last access: 25 November 2017) since 2004, TCCON (Total Carbon Column Observing Network; http://www.tccon.caltech.edu/, last access: 26 November 2017) since 2007 and the BSRN since 2009, among others. Moreover, in 2014, IZO was designated by WMO as a CIMO (Commission for Instruments and Methods of Observation) test bed for aerosols and water vapor remote sensing instruments (WMO, 2014a). Updated details of the site and the observation programs can be found in Cuevas et al. (2017b).

\section{Observational data and methods}

\subsection{Instrument and measurements}

The LDR measurements used in this study were taken by the Izaña BSRN (no. 61, IZA; http://bsrn.aemet.es, last access: 28 November 2017) (García et al., 2012) with a broadband Kipp \& Zonen $\mathrm{CG}(\mathrm{R}) 4$ pyrgeometer (hereafter CG(R)4) mounted on a sun tracker equipped with dome shading. This instrument uses a specially designed silicon window which provides a $180^{\circ}$ field of view (although not hemispherical) with good cosine response. A diamond-like surface protects the outer surface of the window, while the inner surface filters most of solar radiation. The design of the instrument is such that solar radiation absorbed by the windows is conducted away to reduce the solar heating effect.
Table 1. CG(R)4 pyrgeometers installed at IZO.

\begin{tabular}{lrl}
\hline Instrument & $\begin{array}{r}\mathrm{C} \\
\left(\mu \mathrm{V} \mathrm{W}^{-1} \mathrm{~m}^{-2}\right)\end{array}$ & $\begin{array}{l}\text { Calibration } \\
\text { date }\end{array}$ \\
\hline CG(R)4 Kipp \& Zonen no. 080022 & $10.37 \pm 0.34$ & February 2008 \\
CG(R)4 Kipp \& Zonen no. 050783 & $9.39 \pm 0.31$ & June 2014 \\
& $9.41 \pm 0.30$ & March 2017 \\
\hline
\end{tabular}

This fact reduces the need for dome heating correction terms and shading from the sun (McArthur, 2005).

In this study, we analyzed measurements performed with two CG(R)4 series (see Table 1) between 2010 and 2016 at IZO. The CG(R)4 no. 080022 was calibrated by the manufacturer in February 2008 in the Netherlands (Kipp \& Zonen) and the CG(R)4 no. 050783 was calibrated in June 2014 and March 2017 at the Physikalisch-Meteorologisches Observatorium Davos/World Radiation Center (PMOD/WRC). Given the two calibration coefficients of the second instrument (see Table 1), we estimate that its degradation is very small, lower than $0.08 \% \mathrm{yr}^{-1}$.

The World Radiation Monitoring Center (WRMC) recommends performing quality checks on BSRN data, examining physically possible (PP, minimum 40maximum $700 \mathrm{~W} \mathrm{~m}^{-2}$ ) and extremely rare LDR limits (ER, minimum 60 -maximum $500 \mathrm{~W} \mathrm{~m}^{-2}$ ), as well as considering the comparison between LDR and air temperature (Gilgen et al., 1995; Long and Dutton, 2002). We have applied these BSRN quality controls to the IZO LDR measurements and found that the LDR measurements are within the abovementioned limits (Fig. 1).

\subsection{Cloud-free detection}

The cloud-free days were detected by using the algorithm developed by Marty and Philipona (2000). A clear-sky index (CSI) is calculated to separate cloud-free days from cloudy days using accurate measurements of LDR in con- 
junction with air temperature and relative humidity values measured at the station. The CSI is defined as

$\mathrm{CSI}=\epsilon_{\mathrm{A}} / \epsilon_{\mathrm{AC}}$,

where

$\epsilon_{\mathrm{A}}=\mathrm{LDR} / \sigma T^{4}$,

and

$\epsilon_{\mathrm{AC}}=\epsilon_{\mathrm{AD}}+k(e / T)^{1 / 8}$,

where $\sigma$ is the Stefan-Boltzmann constant, $T$ is air temperature $(\mathrm{K}), \epsilon_{\mathrm{AD}}$ is an altitude-dependent emittance of a completely dry atmosphere, $k$ is a location dependent coefficient and $e$ is the water vapor pressure $(\mathrm{Pa})$. $\mathrm{CSI} \leq 1$ indicates cloud-free (no clouds) and CSI $>1$ indicates cloudy sky (Marty and Philipona, 2000).

In order to calculate $\epsilon_{\mathrm{AC}}$, this method requires the evaluation of $\epsilon_{\mathrm{AD}}$ and $k$, as shown in Eq. (4). A sample of known cloud-free days is used to plot $\epsilon_{\mathrm{AC}}$ against $e / T$ (Fig. 2). The cloud-free conditions from this sample is assured by applying the Long and Ackerman method (Long and Ackerman, 2000; adapted for IZO by García et al., 2014). This method is based on surface measurements of global and diffuse solar radiation with a 1 min sampling period and consists of four individual tests applied to normalized global radiation magnitude, maximum diffuse radiation, change in global radiation with time and normalized diffuse radiation ratio variability. We have considered the period 2010-2016 at 11:00 UTC to determine the fitting coefficients of Eq. (4) obtaining the following relationship (Fig. 2):

$\epsilon_{\mathrm{AC}}=(0.218 \pm 0.05)+(0.385 \pm 0.07)(e / T)^{1 / 8}$.

Despite that $\epsilon_{\mathrm{AD}}$ depends on the altitude of the station, we obtained a value of 0.218 for IZO, similar to the values obtained by Marty and Philipona (2000) for stations located between 2230 and $2540 \mathrm{~m}(0.220$ and 0.211 , respectively).

Once we have adjusted the coefficients, the cloud-free cases were selected with a combination of Long and Ackerman and CSI methods. At daytime, we used the Long and Ackerman method, taking into account the period 11:0013:00 UTC for each day. At night-time the CSI was applied in the period 23:00-01:00 UTC. These results were checked by visual examination of 5 min total sky images obtained with a SONA (Automatic Cloud Observation System) camera (Gónzalez et al., 2012) running at IZO. We found that both methods detect $97 \%$ of the visually selected cases. A total of 1161 and 1083 cases were detected for daytime and night-time, respectively, in the period 2010-2016.

\section{Radiative transfer models and input parameters}

The simulations of surface LDR were determined with two RTMs: libRadtran and MODTRAN.

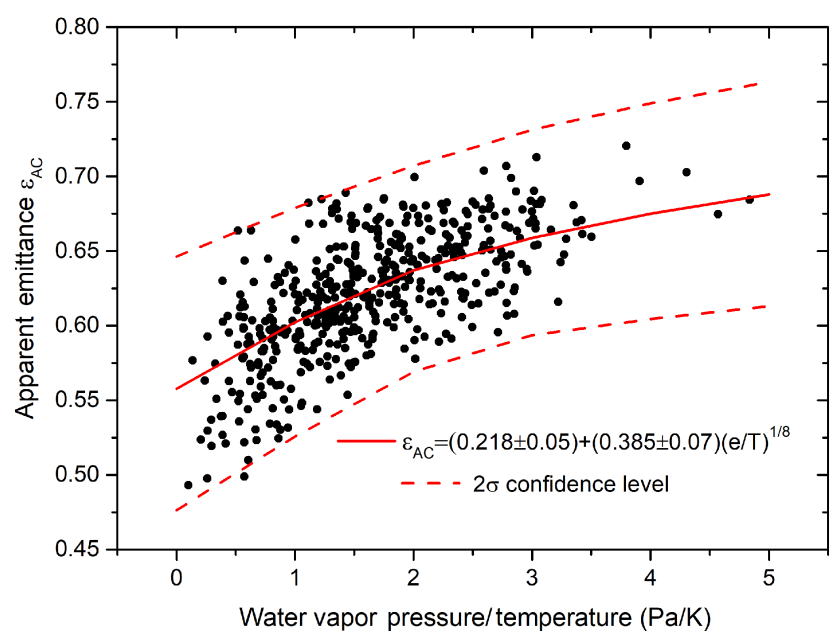

Figure 2. Apparent emittance $\left(\epsilon_{\mathrm{AC}}\right)$ as a function of the ratio of screen level water vapor pressure and temperature at IZO in the period 2010-2016 at 11:00 UTC.

The libRadtran model (freely available from http://www. libradtran.org, last access 20 October 2017; Mayer and Kylling, 2005) used in this work is version 2.0.1 (Emde et al., 2016). The simulations were performed with highly resolved absorption coefficients that were calculated using the absorption band parameterization REPTRAN. It is based on the high-resolution transmission molecular absorption (HITRAN) 2004 spectroscopic database, in which wavelength integrals were parameterized as weighted means over representative wavelengths (Gasteiger et al., 2014). The simulations performed using REPTRAN in the thermal range showed relative differences of about $1 \%$ with respect to simulations performed with high spectral resolution models, and they are 6-7 times better than the simulations done with the LOWTRAN band parameterization (Gasteiger et al., 2014).

This work used is the MODTRAN version 6 (Berk and Hawes, 2017), an atmospheric transmittance and radiance model developed by the US Air Force Research Laboratory in collaboration with Spectral Sciences, Inc. We have selected a band model with a resolution of $1 \mathrm{~cm}^{-1}$ for spectral calculations. The MODTRAN band model molecular spectroscopy is based on the HITRAN database (Rothman et al., 2013).

The main differences between the two models is in the molecular absorption band: while MODTRAN uses the HITRAN database (Rothman et al., 2013), libRadtran uses the absorption band parameterization REPTRAN (Gasteiger et al., 2014).

For both models, the LDR simulations were calculated by using the DISORT (DIScrete Ordinate Radiative Transfer) solvers, developed by Chandrasekhar (1960) and Stamnes et al. $(1988,2000)$, as radiative transfer equation (RTE) solver, and based on the five multi-stream discrete ordinates algorithm. The number of streams used to run DISORT 
was 16 . For each simulation, the integrated downward irradiance was calculated in the spectral range $4-100 \mu \mathrm{m}$.

The two models were run using the same inputs, atmosphere and geometry in order to minimize.

The rest of the inputs measured at IZO are

- Radiosondes: temperature and relative humidity $(\mathrm{RH})$ profiles: in this work, we used the AEMET's meteorological radiosondes dataset. Radiosondes are launched twice a day, at 11:00 and 23:00 UTC at the Güimar station (WMO GRUAN station no. 60018, 105 m a.s.1.). This station is located at the coastline, approximately $15 \mathrm{~km}$ to the southeast of IZO. Vertical profiles of pressure, temperature and relative humidity were obtained with Vaisala RS92 radiosondes (RodriguezFranco and Cuevas, 2013; Carrillo et al., 2016). We have used the radiosonde profiles from the altitude of IZO (2373 m a.s.1.).

- PWV: since January 2009, the PWV has been taken every $1 \mathrm{~h}$ at IZO from a Global Navigation Satellite System (GNSS) receiver considering satellite precise orbits (Romero Campos et al., 2009). In this work, we have used the PWV median measured at 11:00-13:00 and 23:00-01:00 UTC in order to take into account the radiosonde flight time, and hence making a comparison with GNSS observations possible.

- $\mathrm{CO}_{2}$ and $\mathrm{N}_{2} \mathrm{O}$ profiles: the volume mixing ratio (VMR) profiles of atmospheric $\mathrm{CO}_{2}$ and $\mathrm{N}_{2} \mathrm{O}$ trace gases were used. These were obtained from the monthly average profiles performed with the ground-based Fourier transform infrared spectrometer (FTIR) at IZO between 1999 and 2015 (Schneider et al., 2005; García et al., 2014; Barthlott et al., 2015). The FTIR program at IZO is part of the Network for the Detection of Atmospheric Composition Change (NDACC). In this study FTIR climatological profiles have been used. The profiles were scaled on a daily basis with ground-level in situ $\mathrm{CO}_{2}$ and $\mathrm{N}_{2} \mathrm{O}$ mixing ratios, continuously measured at IZO since June 1984 and June 2007, respectively, within the WMO GAW programme (Cuevas et al., 2017b).

- $\mathrm{CO}_{2}$ and $\mathrm{N}_{2} \mathrm{O}$ in situ: since 2007 the $\mathrm{CO}_{2}$ in situ measurements have been taken with the LICOR-7000 NDIR analyzer (Gómez-Peláez and Ramos, 2009; GómezPeláez et al., 2010) and the $\mathrm{N}_{2} \mathrm{O}$ in situ measurements with a VARIAN GC-ECD 3800 (Scheel, 2009). In this work, we used only the night-time (20:00-08:00 UTC) averaged $\mathrm{CO}_{2}$ and $\mathrm{N}_{2} \mathrm{O}$ data because during this period IZO is under background free troposphere conditions, and the observatory is not affected by local and regional sources of such gases.

- AOD: atmospheric aerosols have been included in the simulation process by means of the columnintegrated aerosol optical depth (AOD), extracted from
AERONET (Level 2.0 of version 2, cloud screened and quality ensured). AOD is obtained from solar observations performed with CIMEL sun photometers at different wavelengths (Holben et al., 1998; Dubovik and King, 2000; Dubovik et al., 2006). The Shettle (1990) aerosol model has been used in this study. The default properties are rural type aerosol in the boundary layer, background aerosol above $2 \mathrm{~km}$, spring-summer conditions and a visibility of $50 \mathrm{~km}$. In this work, AOD at $500 \mathrm{~nm}$ was used as model input. For daytime we used the AOD value nearest to 11:00 UTC, and for night-time we used the last available AOD value of the day.

- Total ozone column (TOC): TOC measurements with Brewer spectrometer began at IZO in 1991. Since 2003 IZO has been designated as the Regional Brewer Calibration Center for Europe (RBCC-E; http://www. rbcc-e.org, last access 11 September 2017) and the total ozone program has been part of NDACC network. We have considered daily total ozone mean value as model input.

\subsection{Uncertainty due to the input parameters}

In this section, we have estimated the theoretical uncertainty for the libRadtran and MODTRAN LDR simulations due to the uncertainties in the input parameters. According to the Guide to the Expression of Uncertainty in Measurement (GUM; BIPM et al., 2008), we assumed the type A uncertainties listed in Table 2.

Our uncertainty estimation is based on two steps: first, the LDR simulations were conducted using the measured values for all the input parameters listed in the previous section, obtaining the non-perturbed values (sim). In a second step, we simulated the same sample again but applied the uncertainties listed in Table 2, with the perturbed values $(\operatorname{sim}+\delta$; (Schneider and Hase, 2008; García et al., 2014)). This uncertainty estimation has been applied to those cloud-free days for which all the inputs were available at 11:00 and 23:00 UTC between 2010 and 2016 (1048 and 1014 cases at 11:00 and 23:00 UTC, respectively). Note that the errors of the FTIR $\mathrm{CO}_{2}$ and $\mathrm{N}_{2} \mathrm{O}$ profiles have been theoretically estimated by following the formalism detailed by Rodgers (2000) and assuming the uncertainty sources and values shown in García et al. (2016).

For each uncertainty component we obtain the standard deviation of the measurement residuals from the scatter around the regression line which is related to the correlation coefficient of the least squares fit and the scatter of the perturbed distribution.

The final results of the uncertainty analysis are summarized in Table 3. The uncertainties of the PWV and AOD dominate the total uncertainty with respect to the other components. The uncertainty of PWV presents a scatter of $0.84 \mathrm{~W} \mathrm{~m}^{-2}(0.46 \%)$ at daytime and $0.86 \mathrm{~W} \mathrm{~m}^{-2}(0.48 \%)$ 
Table 2. Assumed type A uncertainty in the input parameters and their corresponding references.

\begin{tabular}{lll}
\hline $\begin{array}{l}\text { Uncertainty } \\
\text { source }\end{array}$ & $\begin{array}{l}\text { Standard uncertainty } \\
(\delta)\end{array}$ & Reference \\
\hline AOD & \pm 0.01 & \\
TOC & $\pm 1 \%$ & Holben et al. (1998); Eck et al. (1999) \\
PWV & $<3.5 \mathrm{~mm}: \pm 20 \%$ & Redondas and Cede (2006) \\
& $\geq 3.5 \mathrm{~mm}: \pm 10 \%$ & \\
$\mathrm{~N}_{2} \mathrm{O}$ in situ & $\pm 0.2 \mathrm{ppbv}$ & Gómeider et al. (2010) \\
$\mathrm{CO}_{2}$ in situ & $\pm 0.1 \mathrm{ppmv}$ & Zellweger et al. (2015) \\
$\mathrm{N}_{2} \mathrm{O}$ profile (FTIR) & $2.37-20 \mathrm{~km}: \sim 1 \%$ & García et al. (2016) \\
& $>20 \mathrm{~km}: 2.0-2.5 \%$ & \\
$\mathrm{CO}_{2}$ profile (FTIR) & $0.3 \%$ & García et al. (2016) \\
Temperature profile & $1080-100 \mathrm{hPa}: 0.2^{\circ} \mathrm{C}$ & \\
& $100-20 \mathrm{hPa}: 0.3^{\circ} \mathrm{C}$ & Vaisala (2013) \\
& $20-3 \mathrm{hPa}: 0.5^{\circ} \mathrm{C}$ & \\
$\mathrm{RH}$ profile & $2 \%$ & Vaisala (2013) \\
\hline
\end{tabular}

Table 3. Estimation of type A uncertainties - in $\mathrm{W} \mathrm{m}^{-2}$ and in \% (in brackets) -, sensitivity (\%), and bias ( $\mathrm{W} \mathrm{m}{ }^{-2}$ ) of the difference between non-perturbed and perturbed LDR simulations (simulation $-($ simulation $+\delta)$ ) with libRadtran and MODTRAN models. The combined uncertainty is calculated as the root square sum of all the uncertainty components.

\begin{tabular}{|c|c|c|c|c|}
\hline \multirow[t]{2}{*}{ Uncertainty component } & \multicolumn{2}{|c|}{ LDR (daytime) } & \multicolumn{2}{|c|}{ LDR (night-time) } \\
\hline & $\begin{array}{r}\mathrm{SD} \text { of } \\
\text { residuals } \\
\mathrm{W} \mathrm{m}^{-2}(\%) \\
(\operatorname{sim}+\delta)\end{array}$ & $\begin{array}{r}\text { regression } \\
(\text { sens/bias) } \\
(\%) / \mathrm{W} \mathrm{m}^{-2}\end{array}$ & $\begin{array}{r}\mathrm{SD} \text { of } \\
\text { residuals } \\
\mathrm{W} \mathrm{m}^{-2}(\%) \\
(\operatorname{sim}+\delta)\end{array}$ & $\begin{array}{r}\text { regression } \\
(\text { sens/bias }) \\
(\%) / \mathrm{W} \mathrm{m}^{-2}\end{array}$ \\
\hline \multicolumn{5}{|l|}{ libRadtran model } \\
\hline AOD & $0.30(0.09)$ & $-0.73 / 1.65$ & $0.23(0.08)$ & $-0.46 / 1.01$ \\
\hline TOC (DU) & $<0.01(<0.01)$ & $<0.01 /<0.01$ & $<0.01(<0.01)$ & $<0.01 /<0.01$ \\
\hline PWV (mm) & $0.84(0.46)$ & $-1.20 / 6.26$ & $0.86(0.48)$ & $-1.42 / 6.89$ \\
\hline $\mathrm{CO}_{2}$ in situ (ppm) & $<0.01(<0.01)$ & $<0.01 /<0.01$ & $<0.01(<0.01)$ & $<0.01 /<0.01$ \\
\hline $\mathrm{N}_{2} \mathrm{O}$ in situ (ppb) & $<0.01(<0.01)$ & $<0.01 /<0.01$ & $<0.01(<0.01)$ & $<0.01 /<0.01$ \\
\hline Temperature profile & $<0.01(<0.01)$ & $<0.01 /<0.01$ & $0.03(<0.01)$ & $<0.01 /<0.01$ \\
\hline RH profile & $<0.01(<0.01)$ & $<0.01 /<0.01$ & $<0.01(<0.01)$ & $<0.01 /<0.01$ \\
\hline Combined uncertainty $(u)$ & \multicolumn{2}{|c|}{$0.89(0.47)$} & \multicolumn{2}{|c|}{$0.88(0.49)$} \\
\hline \multicolumn{5}{|l|}{ MODTRAN model } \\
\hline AOD & $0.39(0.16)$ & $0.59 /-1.37$ & $0.27(0.10)$ & $0.42 /-0.91$ \\
\hline TOC (DU) & $<0.01(<0.01)$ & $<0.01 /<0.01$ & $<0.01(<0.01)$ & $<0.01 / 0.03$ \\
\hline PWV (mm) & $0.85(0.46)$ & $-1.18 / 6.19$ & $0.91(0.50)$ & $-1.48 / 7.03$ \\
\hline $\mathrm{CO}_{2}$ in situ (ppm) & $<0.01(<0.01)$ & $<0.01 /<0.01$ & $<0.01(<0.01)$ & $<0.01 /<0.01$ \\
\hline $\mathrm{N}_{2} \mathrm{O}$ in situ (ppb) & $<0.01(<0.01)$ & $<0.01 /<0.01$ & $<0.01(<0.01)$ & $<0.01 /<0.01$ \\
\hline Temperature profile & $<0.01(<0.01)$ & $<0.01 /<0.01$ & $0.02(<0.01)$ & $<0.01 /<0.01$ \\
\hline $\mathrm{RH}$ profile & $<0.01(<0.01)$ & $<0.01 /<0.01$ & $<0.01(<0.01)$ & $<0.01 /<0.01$ \\
\hline Combined uncertainty $(u)$ & \multicolumn{2}{|c|}{$0.93(0.49)$} & \multicolumn{2}{|c|}{$0.95(0.51)$} \\
\hline
\end{tabular}

at night-time for libRadtran. The results are very similar for MODTRAN, with a scatter of $0.85 \mathrm{~W} \mathrm{~m}^{-2}(0.46 \%)$ at daytime and $0.91 \mathrm{~W} \mathrm{~m}^{-2}(0.50 \%)$ at night-time. The AOD is also a significant uncertainty source with a scatter of $0.30 \mathrm{~W} \mathrm{~m}^{-2}(0.09 \%)$ at daytime and lower scatter at nighttime, observing an LDR bias of $1.01 \mathrm{~W} \mathrm{~m}^{-2}$ for libRadtran, and an LDR bias of $0.39 \mathrm{~W} \mathrm{~m}^{-2}(0.16 \%)$ at day- time for MODTRAN. The PWV uncertainties present lower scatter at daytime than at night-time, contrary to that observed in the study of the AOD uncertainty for both models. In general, we find that the standard deviations of the LDR residuals are rather small: $0.89 \mathrm{~W} \mathrm{~m}^{-2}(0.47 \%)$ and $0.93 \mathrm{~W} \mathrm{~m}^{-2}(0.49 \%)$ at daytime, and $0.88 \mathrm{~W} \mathrm{~m}^{-2}(0.49 \%)$ 

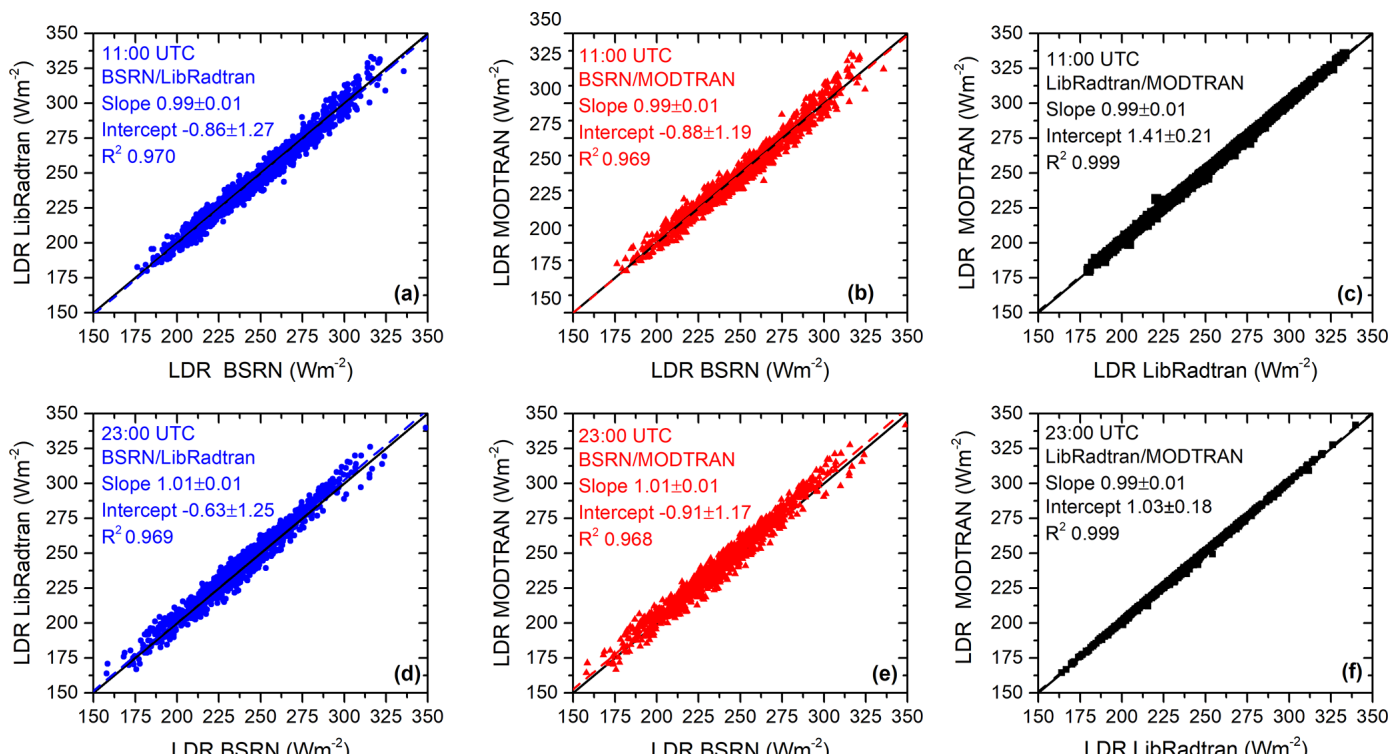

Figure 3. Scatter plot of the LDR $\left(\mathrm{W} \mathrm{m}^{-2}\right)$ simulations with libRadtran (blue) vs. BSRN LDR (W m ${ }^{-2}$ ) at cloud-free (a) daytime and (d) night-time. Scatter plot of the MODTRAN LDR $\left(\mathrm{W} \mathrm{m}^{-2}\right.$; red) vs. BSRN LDR $\left(\mathrm{W} \mathrm{m}^{-2}\right)$ at (b) daytime and (e) night-time, and scatter plot of the MODTRAN LDR (W m ${ }^{-2}$; black) vs. libRadtran LDR $\left(\mathrm{W} \mathrm{m}^{-2}\right)$ at (c) daytime and (f) night-time. The black solid lines show $x=y$. The dashed lines represent the least-square fits and the fitting parameters are shown in the legend.

and $0.95 \mathrm{~W} \mathrm{~m}^{-2}(0.51 \%)$ at night-time, for libRadtran and MODTRAN, respectively.

\section{Results}

\subsection{BSRN and modeled LDR comparison}

In this section, we present the comparison between LDR measured with BSRN and simulated with libRadtran and MODTRAN, considering the available and coincident cloudfree BSRN at daytime and night-time, and the inputs indicated in Sect. 4 at IZO between 2010 and 2016. A total of 1048 measurements at daytime and 1014 measurements at night-time were used.

The observations were averaged over $30 \mathrm{~min}$, in order match the flight time of the radiosonde over IZO. In particular, we averaged over 11:00-11:30 and 23:00-23:30 UTC for daytime and night-time measurements, respectively. The simulations with the two models show excellent agreement at both daytime (Fig. 3a and b) and night-time (Fig. 3d and e). Both models show a very similar performance, as indicated by the least-square fit with slope of 0.99 and $R^{2}$ of $\sim 0.970$, with a slightly better similitude during the night-time (Fig. 3c and $\mathrm{f}$ ).

In order to quantify the difference between BSRN LDR and simulations, we have calculated the absolute LDR difference or bias (simulation-measurement, in $\mathrm{W} \mathrm{m}^{-2}$ ), and relative LDR differences ((simulation - measurement)/measurement, in \%). As a summary, Table 4 lists the metrics used to quantify these differences.
The results obtained show that both models have a very similar behavior and yield similar performances, as seen in Fig. $3 \mathrm{c}$ and $\mathrm{f}$. Both models underestimate the LDR at daytime by $-1.73 \mathrm{~W} \mathrm{~m}^{-2}(-1.1 \%)$ for BSRN/libRadtran and by $-1.79 \mathrm{~W} \mathrm{~m}^{-2}(-0.7 \%)$ for BSRN/MODTRAN. In addition, at night-time, both models overestimate with respect to BSRN LDR by $0.15 \mathrm{~W} \mathrm{~m}^{-2}(0.1 \%)$ for BSRN/libRadtran, and by $1.14 \mathrm{~W} \mathrm{~m}^{-2}(0.5 \%)$ for BSRN/MODTRAN. The RMS is $<3 \%$ for both comparisons at daytime and $<2 \%$ at night-time.

The comparison between BSRN LDR and simulations present better results (lower MB, SD and RMS) during nighttime than during daytime. These results also agree with other short-term studies. For example, Dürr et al. (2005) found differences between LDR measurements and simulations with MODTRAN of -3.2 and $1.5 \mathrm{~W} \mathrm{~m}^{-2}$ for daytime (94 cases) and night-time (274 cases), respectively. Wacker et al. (2009) compared the measurements and simulations with three different models for 39 cloud-free nights in Payerne, finding differences of $-1.2 \pm 2.5 \mathrm{~W} \mathrm{~m}^{-2}$ with MODTRAN and $6.0 \pm 2.9 \mathrm{~W} \mathrm{~m}^{-2}$ with LOWTRAN. Viúdez-Mora et al. (2009) found differences of $-2.7 \pm 3.4 \mathrm{~W} \mathrm{~m}^{-2}$ for a total of 44 night-time cases between LDR measurements and simulations with SBDART in Payerne.

According to the results obtained in Sect. 4.1, the uncertainties of PWV and AOD dominate the total uncertainty; thus, the LDR bias was analyzed.

The box plot of LDR bias for different PWV is presented in Fig. $4 \mathrm{a}$ and $\mathrm{b}$. Both models tend to underestimate LDR (up to $5 \mathrm{~W} \mathrm{~m}^{-2}$ ) in the case of daytime measurements with 
Table 4. Statistics for the LDR bias between libRadtran and MODTRAN simulations and BSRN LDR at IZO (in $\mathrm{W} \mathrm{m}^{-2}$ ) performed with daytime (1048 cases) and night-time (1014 cases) data in the period 2010-2016 (MB, mean bias; RMS, root mean square of the bias; $R^{2}$ ). The statistics for the relative bias are in brackets (in \%).

\begin{tabular}{lrrrrrrrr}
\hline & \multicolumn{3}{c}{ Daytime } & & \multicolumn{3}{c}{ Night-time } \\
\cline { 2 - 6 } \cline { 6 - 8 } & MB & RMS & $R^{2}$ & & MB & RMS & $R^{2}$ \\
\hline BSRN/libRadtran & -1.73 & 6.52 & 0.970 & & 0.15 & 4.41 & 0.969 \\
& $(-1.1 \%)$ & $(2.6 \%)$ & & & $(0.1 \%)$ & $(1.8 \%)$ & \\
\hline BSRN/MODTRAN & -1.79 & 6.30 & 0.969 & & 1.14 & 4.53 & 0.968 \\
& $(-0.7 \%)$ & $(2.5 \%)$ & & & $(0.5 \%)$ & $(1.9 \%)$ & \\
libRadtran/MODTRAN & 0.94 & 1.26 & 0.999 & & 1.00 & 1.23 & 0.999 \\
& $(0.4 \%)$ & $(0.5 \%)$ & & & $(0.4 \%)$ & $(0.5 \%)$ & \\
\hline
\end{tabular}

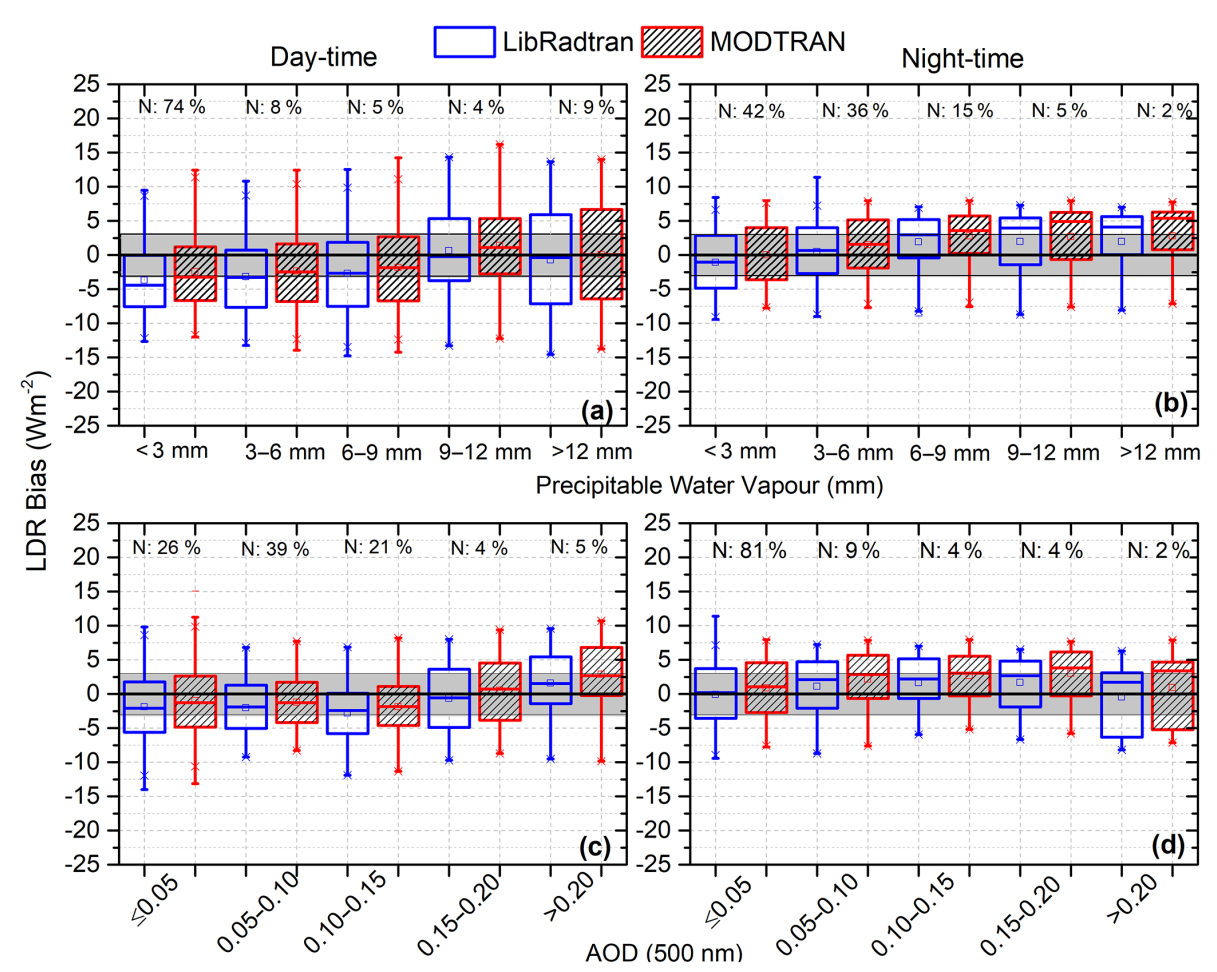

Figure 4. Box plot of mean LDR bias (model-BSRN in $\mathrm{W} \mathrm{m}^{-2}$ ) vs. PWV (mm) (a) at daytime (b) at night-time, and vs. AOD (500 nm) (c) at daytime and (d) at night-time between 2010 and 2016. Lower and upper boundaries for each box are the 25th and 75th percentiles; the solid line is the median value; the crosses indicate values out of the 1.5-fold box area (outliers); and hyphens are the maximum and minimum values. The blue boxes represent libRadtran/BSRN and the red ones represent MODTRAN/BSRN. $N$ indicates the number the measurements in each interval. Shadings show the range of instrumental error $\left( \pm 3 \mathrm{~W} \mathrm{~m}^{-2}\right)$.

PWV $<9 \mathrm{~mm}$ (Fig. 4a). An LDR bias around zero is observed for higher PWV, although it is necessary to emphasize that the number of data in this PWV range (between 4 and $5 \%$ ) is much lower. At night-time, the dependence of LDR bias with PWV shows a negligible bias under dry conditions (PWV $<6 \mathrm{~mm}$ ), and a slight overestimation of both models (up to $+5 \mathrm{~W} \mathrm{~m}^{-2}$ ) for higher PWV values (Fig. 4b). These results are consistent with those obtained by Gröbner et al. (2014) and Nyeki et al. (2017) which argue that the World Infrared Standard Group (WISG) of pyrgeometers has a neg- ative bias of about $5 \mathrm{~W} \mathrm{~m}^{-2}$ under cloud-free conditions and PWV $>10 \mathrm{~mm}$.

Similar results were observed in Fig. $4 \mathrm{c}$ and d, where the dependence of LDR bias with AOD at $500 \mathrm{~nm}$ is shown. This may be due to the fact that PWV and AOD are not completely independent at the Izaña Observatory. In fact these parameters show a moderate correlation $\left(R^{2}=0.27\right.$ in daytime and $R^{2}=0.19$ in night-time). The reason is that the Saharan air layer (SAL) intrusions into the subtropical free troposphere over the North Atlantic are not only associated with dust- 


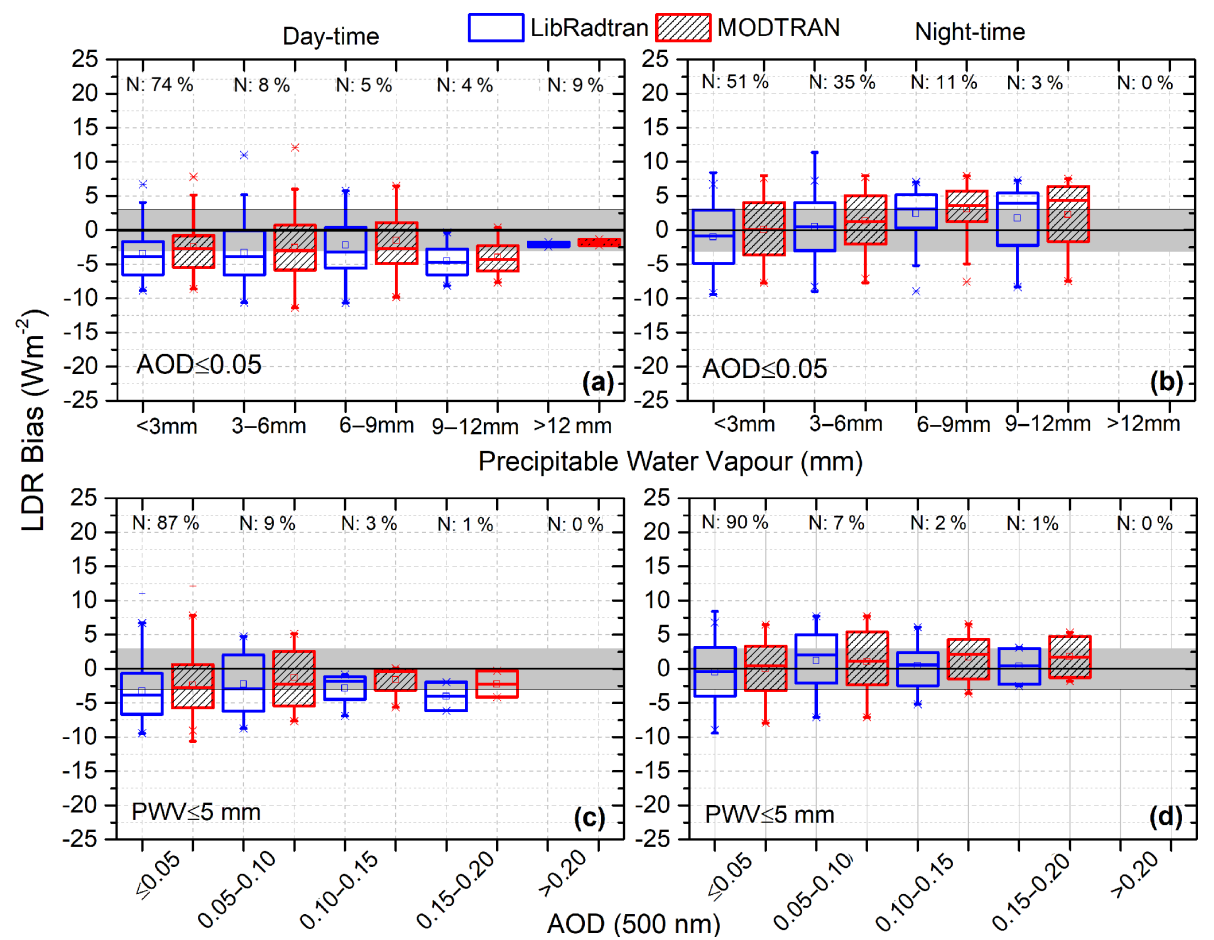

Figure 5. Box plot of mean LDR bias (model-BSRN in $\mathrm{W} \mathrm{m}^{-2}$ ) vs. PWV (mm) (a) at daytime and (b) at night-time for AOD $\leq 0.05$, and vs. AOD at $500 \mathrm{~nm}$ (c) at daytime and (d) night-time for PWV $\leq 5 \mathrm{~nm}$ between 2010 and 2016 at IZO. Box plots are defined as in Fig. 4.

laden air masses (higher values of AOD); they are also associated with more content in water vapor (higher PWV) as described by Rodriguez-Franco and Cuevas (2013) and Andrey et al. (2014). The Saharan dust intrusions in the Canary Islands have a pulsating character, especially in summer, alternating pristine days with periods of hazy days (Cuevas et al., 2017a).

In order to separate the dependence of LDR bias of PWV from AOD and viceversa, we have analyzed, on one hand, the LDR bias as a function of PWV considering very low aerosols conditions (AOD $\leq 0.05$; Fig. 5a and b) and, on the other hand, the LDR bias as a function of AOD for very dry conditions (PWV $\leq 5 \mathrm{~mm}$ ) according to WMO (2014b) criteria (Fig. 5c and d).

An almost flat negative offset in LDR bias is observed in the case of $\mathrm{AOD} \leq 0.05$ daytime data for a relatively large range of PWV, while a larger positive bias is observed at night-time for higher PWV values (Fig. 5a and b, respectively). These results corroborate the dependence of LDR bias with PWV for all conditions found in Fig. $4 \mathrm{~b}$.

The small differences in LDR bias vs. PWV (close to the instrumental error) found between daytime and night-time are not currently understood. It is likely that this different behavior between day and night may be associated with instrumental measurements (Ohmura et al., 1998; McArthur, 2005), but we do not preclude that it could be also related to inaccuracies in the model input parameters during daytime, e.g., inaccuracies in the observed temperature/humidity pro- files due to different heating of the radiosonde sensors by solar radiation. Dirksen et al. (2014) studied the effects on the RS92 temperature and humidity measurements and they estimated this uncertainty to be $0.15 \mathrm{~K}$ for night-time temperature measurements and approximately $0.6 \mathrm{~K}$ at $25 \mathrm{~km}$ during daytime.

Concerning the LDR bias dependence with AOD for very dry conditions (PWV $\leq 5 \mathrm{~mm}$; Fig. $5 \mathrm{c}$ ), we observe a nearly constant negative bias at daytime, similar to that found for clean conditions (AOD $\leq 0.05$; Fig. $5 \mathrm{a}$ ), while the LDR bias vs. AOD at night-time (Fig. 5d) is almost zero.

Some authors claim that dust particles might modify the transport of both shortwave and longwave radiation through the atmosphere by scattering and absorption processes and that dust radiative effects in the infrared are thus nonnegligible (Otto et al., 2007; Meloni et al., 2018). Our results point to an increase in the LDR bias during daytime as the AOD increases (Fig. 4c), which might indicate LDR underestimation by the models which do not capture the aforementioned dust absorption and scattering processes. Notice that there is no equivalent positive trend in LDR bias for higher PWV values (Fig. 4a), suggesting that this LDR bias trend is basically caused by an increase in atmospheric dust content. Unfortunately we cannot confirm these results in a dry atmosphere (removing the effects of water vapor) due to the lack of relatively high AOD data under PWV $\leq 5 \mathrm{~mm}$ conditions (Fig. 5c). It would be necessary to undertake specific research on dust effects in LDR performing additional model 

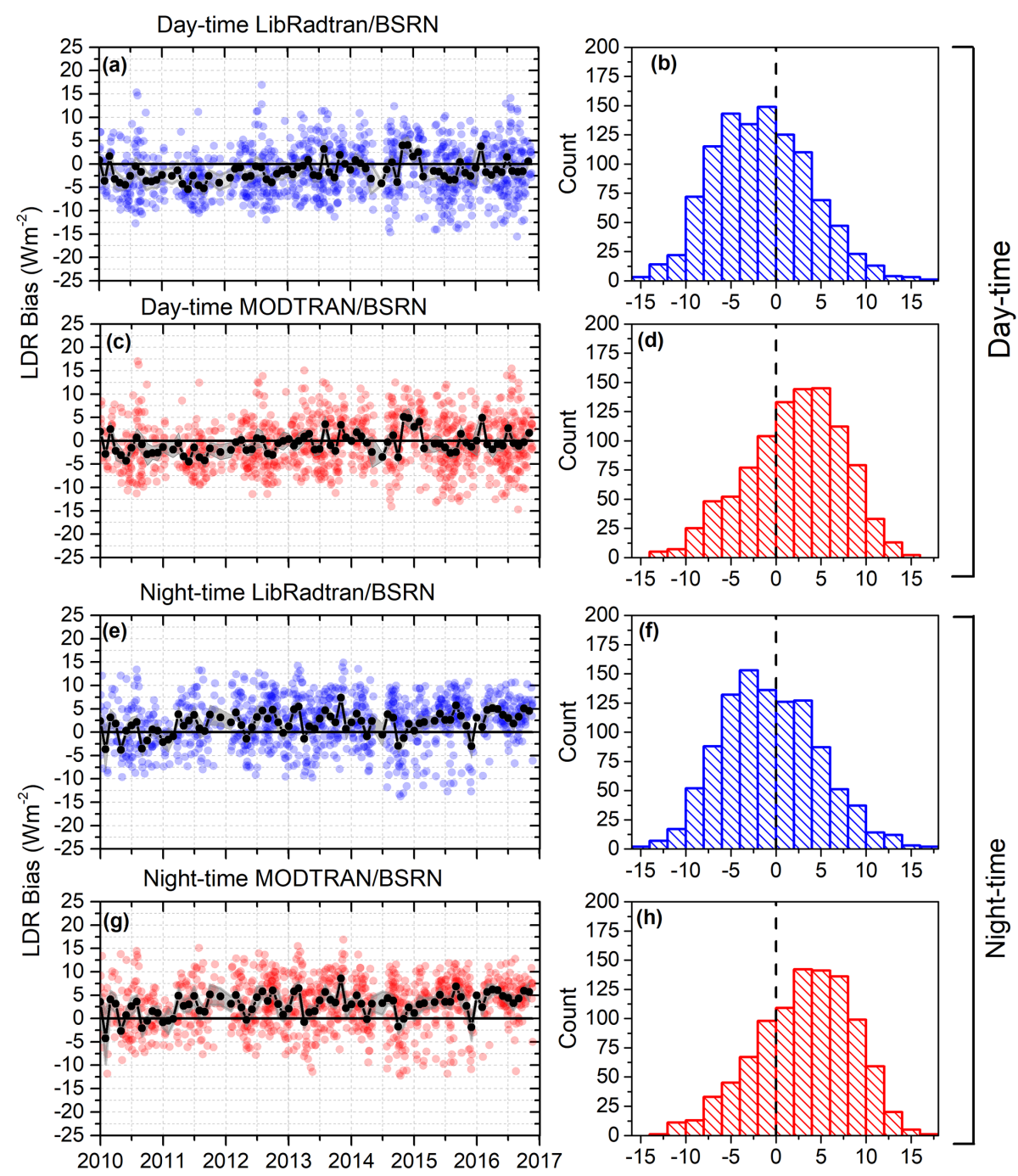

Figure 6. Time series and histogram of LDR bias (model-BSRN in $\mathrm{W} \mathrm{m}^{-2}$ ) between 2010 and 2016 at IZO. The blue and red dots represent the instantaneous bias for libRadtran/BSRN and MODTRAN/BSRN, respectively. The black dots represent the monthly mean bias. The grey shadings show the range of \pm 1 SEM (standard error of the monthly mean bias).

simulations for different sets of dust particle size distribution and refractive index, as proposed by Meloni et al. (2018), to confirm that the observed positive LDR bias for high AOD values during daytime is caused by mineral dust particles.

\subsubsection{Temporal stability}

We have analyzed the temporal stability of the simulation-measurement bias time series during daytime and night-time in order to assess the continuity and consistency of these time series (Fig. 6). We define a bias drift as the linear trend of monthly mean bias, while the change points (changes in the monthly mean bias time series) are analyzed by using a robust rank order change point test (Lanzante, 1996).
By applying this change point test, we identified October 2012 as the change point in the monthly mean bias time series at daytime and night-time for both libRadtran/BSRN and MODTRAN/BSRN time series at $99 \%$ confidence level (Fig. 6). When analyzing the BSRN LDR and the simulated LDR time series separately, we do not observe any change in the simulated LDR, but a change point in the BSRN LDR time series at both daytime and night-time. This change point (October 2012) coincided with a change in the location of the instrumentation within the IZO facilities. The instrument was moved to ground level for approximately a month, while work was undertaken. 


\section{Summary and conclusions}

Cloud-free longwave downward radiation (LDR) measured at the BSRN Izaña Atmospheric Observatory was compared with two complex RTMs, libRadtran v2.0.1 and MODTRAN v6, in the period 2010-2016, for a high number of cases (2062) grouped into daytime (11:00 UTC; 1048 cases) and night-time (23:00 UTC; 1014 cases) datasets. IZO is an optimal station to carry out this study, because all the model input parameters (precipitable water vapor, aerosol optical depth, total ozone, $\mathrm{N}_{2} \mathrm{O}$ in situ, $\mathrm{CO}_{2}$ in situ, $\mathrm{CO}_{2}$ profile and meteorological radiosondes) are measured at the station.

The agreement between measurements and simulations is excellent and very similar for both models. The mean bias (simulations-BSRN measurements) is $-1.73 \mathrm{~W} \mathrm{~m}^{-2}(-1.1 \%)$ and $0.15 \mathrm{~W} \mathrm{~m}^{-2}(0.1 \%)$ for libRadtran/BSRN at daytime and night-time UTC, respectively, and $-1.79 \mathrm{~W} \mathrm{~m}^{-2}(-0.7 \%)$ and $1.14 \mathrm{~W} \mathrm{~m}^{-2}(0.5 \%)$ for MODTRAN/BSRN at daytime and night-time, respectively. Both comparisons showed a RMS $<3 \%$ at daytime and $<2 \%$ at night-time. The mean bias and RMS are lower than the instrumental uncertainty $\left( \pm 3 \mathrm{~W} \mathrm{~m}^{-2} ; 2 \%\right.$; Ohmura et al., 1998; McArthur, 2005).

The MODTRAN and libRadtran performance is very similar. Both models have demonstrated to be very useful tools for LDR quality control and for assessing the impact of atmospheric constituents on the Earth-atmosphere energy balance.

From our study, we state that the absolute differences between BSRN measurements and simulations depend mainly on water vapor and dust aerosols. The observed night-time difference between models and measurements of $+5 \mathrm{~W} \mathrm{~m}^{-2}$ for PWV $>10 \mathrm{~mm}$ supports previous measurements studies that report the existence of an offset between the World Infrared Standard Group of Pyrgeometers (WISG), which serves as reference for atmospheric longwave radiation measurements, and the SI. Concerning the possible influence of aerosols, and specifically atmospheric dust, on LDR differences between models and measurements, our preliminary results show a greater underestimation (about $-3 \mathrm{~W} \mathrm{~m}^{-2}$ ) of modeled LDR as AOD increases (AOD > 0.2) during daytime and dry atmosphere (PWV $<5 \mathrm{~mm}$ ), probably because the models might not have correctly parametrized dust absorption and scattering processes. In fact, the LDR bias between day and night-time is currently not fully understood, and further specific analyses are needed to identify and quantify the contribution of the different possible causes.

Considering that the BSRN measurement accuracy target for LDR is $\pm 2 \mathrm{~W} \mathrm{~m}^{-2}$, the average observed LDR change from 24 BSRN sites since early 1990s has been $+2 \mathrm{~W} \mathrm{~m}^{-2}$ decade $^{-1}$ (Wild, 2017) as a result of the increase of the greenhouse effect and that the CMIP5 projections estimate LDR increases between $1.7 \mathrm{~W} \mathrm{~m}^{-2} \mathrm{decade}^{-1}$ (RCP4.5) and $2.2 \mathrm{~W} \mathrm{~m}^{-2}$ decade $^{-1}$ (RCP8.5) over the period 20102013 (Wild et al., 2015; Wild, 2017), it is crucial to ensure good consistency between LDR observations and estimates with models, such as the one found in this study. Taking into account the present LDR measurement accuracy, a period of less than 2 decades is necessary for assessing its impact on climate change in its entirety.

Data availability. The measurements of longwave downward radiation at BSRN Izaña are available at https://doi.pangaea.de/10. 1594/PANGAEA.882526 (Cuevas-Agulló, 2017).

Competing interests. The authors declare that they have no conflict of interest.

Acknowledgements. This work has been developed within the framework of the activities of the World Meteorological Organization (WMO) Commission for Instruments and Methods of Observations (CIMO) Izaña test bed for aerosols and water vapor remote sensing instruments. The authors are grateful to the libRadtran team for their assistance with the radiative transfer simulations performed in this paper. AERONET Sun photometers at Izaña have been calibrated within the AERONET Europe TNA, supported by the European Union Horizon 2020 research and innovation program under grant agreement no. 654109 (ACTRIS-2). This research benefited from the results of the projects INMENSE and the POLARMOON (funded by the Ministerio de Economía y Competividad of Spain: CGL2016-80688-P and CTM2015-66742-R, respectively). We also acknowledge our colleague Celia Milford for improving the English of the manuscript.

Edited by: Slimane Bekki

Reviewed by: two anonymous referees

\section{References}

Andrey, J., Cuevas, E., Parrondo, M., Alonso-Pérez, S., Redondas, A., and Gil-Ojeda, M.: Quantification of ozone reductions within the Saharan air layer through a 13-year climatologic analysis of ozone profiles, Atmos. Environ., 84, 28-34, https://doi.org/10.1016/j.atmosenv.2013.11.030, 2014.

Ångström, A.: A study of the radiation of the atmosphere, Smithsonian Miscellaneous Collection, 65, 1-159, 1918.

Barthlott, S., Schneider, M., Hase, F., Wiegele, A., Christner, E., González, Y., Blumenstock, T., Dohe, S., García, O. E., Sepúlveda, E., Strong, K., Mendonca, J., Weaver, D., Palm, M., Deutscher, N. M., Warneke, T., Notholt, J., Lejeune, B., Mahieu, E., Jones, N., Griffith, D. W. T., Velazco, V. A., Smale, D., Robinson, J., Kivi, R., Heikkinen, P., and Raffalski, U.: Using $\mathrm{XCO}_{2}$ retrievals for assessing the long-term consistency of NDACC/FTIR data sets, Atmos. Meas. Tech., 8, 1555-1573, https://doi.org/10.5194/amt-8-1555-2015, 2015.

Berk, A. and Hawes, F.: Validation of MODTRAN ${ }^{\circledR} 6$ and its line-by-line algorithm, J. Quant. Spectrosc. Ra. 203, 542-556, https://doi.org/10.1016/j.jqsrt.2017.03.004, 2017. 
Berk, A., Acharya, P. K., Anderson, G., Chetwynd, J. H., and Hoke, M. L.: Reformulation of the MODTRAN band model for higher spectral resolution, in: Proceedings spue the international society for opitcal engineering, International Society for Optical Engineering, SSSI Report No. sr133, PIE AeroSense meeting, Orlando, FL, 190-198, 2000.

BIPM, IFCC, and ISO: IUPAP and OIML: Evaluation of measurement data, Supplement 1, https://www.bipm.org/utils/ common/documents/jcgm/JCGM_100_2008_E.pdf (last acccess: 9 June 2018), 2008.

Brunt, D.: Notes on radiation in the atmosphere, Q. J. Roy. Meteorol. Soc., 58, 389-420, 1932.

Brutsaert, W.: The roughness length for water vapor sensible heat, and other scalars, J. Atmos. Sci., 32, 2028-2031, 1975.

Carrillo, J., Guerra, J., Cuevas, E., and Barrancos, J.: Characterization of the Marine Boundary Layer and the Trade-Wind Inversion over the Sub-tropical North Atlantic, Bound.-Lay. Meteorol., 158, 311-330, https://doi.org/10.1007/s10546-015-0081-1, 2016.

Chandrasekhar, S.: The stability of non-dissipative Couette flow in hydromagnetics, P. Natl. Acad. Sci. USA, 46, 253-257, 1960.

Cuevas, E., Gómez-Peláez, A., Rodríguez, S., Terradellas, E., Basart, S., García, R., García, O., and Alonso-Pérez, S.: The pulsating nature of large-scale Saharan dust transport as a result of interplays between mid-latitude Rossby waves and the North African Dipole Intensity, Atmos. Environ., 167, 586-602, https://doi.org/10.1016/j.atmosenv.2017.08.059, 2017a.

Cuevas, E., Milford, C., Bustos, J. J., del Campo-Hernández, G., García, O. E., Gómez-Peláez, R. D., Guirado-Fuentes, C., Marrero, C., Prats, N., Ramos, R., Redondas, A., Reyes, E., Rodríguez, S., Romero-Campos, P., Scheneider, M., Belmonte, J., Yela, M., Almansa, F., Barreto, A., López-Solano, C., Basart, S., Terradellas, E., Afonso, S., Bayo, C., Berjón, A., Bethencourt, J., Carreño, V., Castro, N. J., Cruz, A. M., Damas, M., De Ory-Ajamil, F., García, M. I., Gómez-Trueba, V., González, Y., Hernández, C., Hernández, Y., Hernández-Cruz, B., Jover, M., León, S., López-Fernández, R., López-Solano, J., Rodríguez, E., Rodríguez-Franco, J., Rodríguez-Valido, M., Sálamo, C., Sanromá, E., Santana, D., Santo-Tomás, F., Sepúlveda, E., Sierra, M., and Sosa, E.: Izaña Atmospheric Research Center Activity Report 2015-2016, State Meteorological Agency (AEMET), Spain, $2017 \mathrm{~b}$.

Cuevas-Agulló, E.: Basic and other measurements of radiation at station Izana (2017-10), Izaña Atmospheric Research Center, Meteorological State Agency of Spain, PANGAEA, https://doi. pangaea.de/10.1594/PANGAEA.882526, 2017.

Dirksen, R. J., Sommer, M., Immler, F. J., Hurst, D. F., Kivi, R., and Vömel, H.: Reference quality upper-air measurements: GRUAN data processing for the Vaisala RS92 radiosonde, Atmos. Meas. Tech., 7, 4463-4490, https://doi.org/10.5194/amt-7-4463-2014, 2014.

Dubovik, O. and King, M. D.: A flexible inversion algorithm for retrieval of aerosol optical properties from Sun and sky radiance measurements, J. Geophys. Res.-Atmos., 105, 20673-20696, 2000.

Dubovik, O., Sinyuk, A., Lapyonok, T., Holben, B. N., Mishchenko, M., Yang, P., Eck, T. F., Volten, H., Munoz, O., Veihelmann, B., Van der Zande, W. J., Leon, J. F., Sorokin, M., and Slutsker, I.: Application of spheroid models to account for aerosol particle nonsphericity in remote sensing of desert dust, J. Geophys. Res.Atmos., 111, D11208, https://doi.org/10.1029/2005JD006619, 2006.

Dupont, J.-C., Haeffelin, M., Drobinski, P., and Besnard, T.: Parametric model to estimate clear-sky longwave irradiance at the surface on the basis of vertical distribution of humidity and temperature, J. Geophys. Res.-Atmos., 113, D07203, https://doi.org/10.1029/2007JD009046, 2008.

Dürr, B., Philipona, R., Schubiger, F., and Ohmura, A.: Comparison of modeled and observed cloud-free longwave downward radiation over the Alps, Meteorol. Z., 14, 47-55, https://doi.org/10.1127/0941-2948/2005/0014-0047, 2005.

Dutton, E. G.: An extended comparison between LOWTRAN7 computed and observed broadband thermal irradiances: Global extreme and intermediate surface conditions, J. Atmos. Ocean. Tech., 10, 326-336, https://doi.org/10.1175/15200426(1993)010<0326:AECBLC>2.0.CO;2, 1993.

Eck, T., Holben, B., Reid, J., Dubovik, O., Smirnov, A., O'neill, N., Slutsker, I., and Kinne, S.: Wavelength dependence of the optical depth of biomass burning, urban, and desert dust aerosols, J. Geophys. Res.-Atmos., 104, 31333-31349, https://doi.org/10.1029/1999JD900923, 1999.

Emde, C., Buras-Schnell, R., Kylling, A., Mayer, B., Gasteiger, J., Hamann, U., Kylling, J., Richter, B., Pause, C., Dowling, T., and Bugliaro, L.: The libRadtran software package for radiative transfer calculations (version 2.0.1), Geosci. Model Dev., 9, 1647-1672, https://doi.org/10.5194/gmd-9-1647-2016, 2016.

García, O. E., Schneider, M., Hase, F., Blumenstock, T., Sepúlveda, E., and González, Y.: Quality assessment of ozone total column amounts as monitored by ground-based solar absorption spectrometry in the near infrared $\left(>3000 \mathrm{~cm}^{-1}\right)$, Atmos. Meas. Tech., 7, 3071-3084, https://doi.org/10.5194/amt-7-3071-2014, 2014.

García, O. E., Sepúlveda, E., Schneider, M., Hase, F., August, T., Blumenstock, T., Kühl, S., Munro, R., Gómez-Peláez, Á. J., Hultberg, T., Redondas, A., Barthlott, S., Wiegele, A., González, Y., and Sanromá, E.: Consistency and quality assessment of the Metop-A/IASI and Metop-B/IASI operational trace gas products $\left(\mathrm{O}_{3}, \mathrm{CO}, \mathrm{N}_{2} \mathrm{O}, \mathrm{CH}_{4}\right.$, and $\left.\mathrm{CO}_{2}\right)$ in the subtropical North Atlantic, Atmos. Meas. Tech., 9, 2315-2333, https://doi.org/10.5194/amt9-2315-2016, 2016.

García, R. D., Ramos, R., Cuevas, E., Cachorro, V. E., and de Frutos, A. M.: Status of the Izaña BSRN station, Optica Pura y Aplicada, 45, 51-55, 2012.

García, R. D., García, O. E., Cuevas, E., Cachorro, V. E., Romero-Campos, P. M., Ramos, R., and de Frutos, A. M.: Solar radiation measurements compared to simulations at the BSRN Izaña station. Mineral dust radiative forcing and efficiency study, J. Geophys. Res.-Atmos., 119, 179-194, https://doi.org/10.1002/2013JD020301, 2014.

Gasteiger, J., Emde, C., Mayer, B., Buras, R., Buehler, S., and Lemke, O.: Representative wavelengths absorption parameterization applied to satellite channels and spectral bands, J. Quant. Spectrosc. Ra., 148, 99-115, https://doi.org/10.1016/j.jqsrt.2014.06.024, 2014.

Gilgen, H., Whitlock, C., Koch, F., Müller, G., Ohmura, A., Steiger, D., and Wheeler, R.: Technical Plan for BSRN (Baseline Surface Radiation Network) Data Management, Version 2.1, WMO/TDNo. 443, WCRP/WMO, 1995. 
Gómez-Peláez, A. and Ramos, R.: Improvements in the Carbon Dioxide and Methane Continuous Measurement Programs at Izaña Global GAW Station (Spain) during 2007-2009, GAW report 194, 7-10 September 2009, Jena, Germany, 133-138, 2009.

Gómez-Peláez, A., Ramos, R., Cuevas, E., and Gómez-Trueba, V.: 25 years of continuous $\mathrm{CO}_{2}$ and $\mathrm{CH}_{4}$ measurements at Izaña Global GAW mountain station: annual cycles and interannual trends, in: Proceedings of the Symposium on Atmospheric Chemistry and Physics at Mountain Sites, ACP Symposium, 810 June 2010, Interlaken, Switzerland, 157-159, 2010.

Gónzalez, Y., López, C., and Cuevas Agulló, E.: Automatic observation of cloudiness: Analysis of all-sky images, in: WMO Technical Conference on Meteorological and Environmental Instruments and Methods of Observation, Session 3, 16-18 October 2012, Brussels, Belgium, http://www.wmo.int/pages/prog/www/IMOP/publications/

IOM-109_TECO-2012/Programme_TECO-2012.html

(last access: 9 June 2018), 2012.

Gröbner, J., Reda, I., Wacker, S., Nyeki, S., Behrens, K., and Gorman, J.: A new absolute reference for atmospheric longwave irradiance measurements with traceability to SI units, J. Geophys. Res.-Atmos., 119, 7083-7090, 2014.

Holben, B., Eck, T., Slutsker, I., Tanré, D., Buis, J., Setzer, A., Vermote, E., Reagan, J., Kaufman, Y., Nakajima, T., Lavenu, F., Jankowiak, I., and Smirnov, A.: AERONET A Federated Instrument Network and Data Archive for Aerosol Characterization, Remote Sens. Environ., 66, 1-16, https://doi.org/10.1016/S00344257(98)00031-5, 1998.

Iacono, M. J., Delamere, J. S., Mlawer, E. J., Shephard, M. W., Clough, S. A., and Collins, W. D.: Radiative forcing by long-lived greenhouse gases: Calculations with the AER radiative transfer models, J. Geophys. Res.-Atmos., 113, D13103, https://doi.org/10.1029/2008JD009944, 2008.

Idso, S. B. and Jackson, R. D.: Thermal radiation from the atmosphere, J. Geophys. Res., 74, 5397-5403, 1969.

Iziomon, M. G., Mayer, H., and Matzarakis, A.: Downward atmospheric longwave irradiance under clear and cloudy skies: Measurement and parameterization, J. Atmos. Sol.-Terr. Phy., 65, 1107-1116, 2003.

Lanzante, J. R.: Resistant, robust and non-parametric techniques for the analysis of climate data: Theory and examples, including applications to historical radiosonde station data, Int. J. Climatol., 16, 1197-1226, 1996.

Long, C. N. and Ackerman, T. P.: Identification of clear skies from broadband pyranometer measurements and calculation of downwelling shortwave cloud effects, J. Geophys. Res.-Atmos., 105, 15609-15626, https://doi.org/10.1029/2000JD900077, 2000.

Long, C. N. and Dutton, E. G.: BSRN Global Network recommended QC tests, V2.x, BSRN Technical Report, hdl:10013/ epic.38770.d001, 2002.

Long, C. N. and Turner, D. D.: A method for continuous estimation of clear-sky downwelling longwave radiative flux developed using ARM surface measurements, J. Geophys. Res.-Atmos., 113, D18206, https://doi.org/10.1029/2008JD009936, 2008.

Marty, C. and Philipona, R.: Clear-sky index to separate clear-sky from cloudy-sky situations in climate research, Geophys. Re. Lett., 27, 2649-2652, 2000.

Marty, C., Philipona, R., Delamere, J., Dutton, E. G., Michalsky, J., Stamnes, K., Storvold, R., Stoffel, T., Clough, S. A., and
Mlawer, E. J.: Downward longwave irradiance uncertainty under arctic atmospheres: Measurements and modeling, J. Geophys. Res.-Atmos., 108, 4358, https://doi.org/10.1029/2002JD002937, 2003.

Mayer, B. and Kylling, A.: Technical note: The libRadtran software package for radiative transfer calculations - description and examples of use, Atmos. Chem. Phys., 5, 1855-1877, https://doi.org/10.5194/acp-5-1855-2005, 2005.

McArthur, L.: Baseline Surface Radiation Network (BSRN), WMO/TD-No. 879, WCRP/WMO, hdl:10013/epic.52032.d001, 2005.

Meloni, D., di Sarra, A., Brogniez, G., Denjean, C., De Silvestri, L., Di Iorio, T., Formenti, P., Gómez-Amo, J. L., Gröbner, J., Kouremeti, N., Liuzzi, G., Mallet, M., Pace, G., and Sferlazzo, D. M.: Determining the infrared radiative effects of Saharan dust: a radiative transfer modelling study based on vertically resolved measurements at Lampedusa, Atmos. Chem. Phys., 18, 43774401, https://doi.org/10.5194/acp-18-4377-2018, 2018.

Morcrette, J. J.: The surface downward longwave radiation in the ECMWF forecast system, J. Climate, 15, 1875-1892, 2002.

Nyeki, S., Wacker, S., Gröbner, J., Finsterle, W., and Wild, M.: Revising shortwave and longwave radiation archives in view of possible revisions of the WSG and WISG reference scales: methods and implications, Atmos. Meas. Tech., 10, 3057-3071, https://doi.org/10.5194/amt-10-3057-2017, 2017.

Ohmura, A., Gilgen, H., Hegner, H., Müller, G., Wild, M., Dutton, E. G., Forgan, B., Fröhlich, C., Philipona, R., Heimo, A., König-Langlo, G., McArthur, B., Pinker, R., Whitlock, C. H., and Dehne, K.: Baseline Surface Radiation Network (BSRN/WCRP): New precision radiometry for climate research, B. Am. Meteorol. Soc., 79, 2115-2136, https://doi.org/10.1175/15200477(1998)079<2115:BSRNBW>2.0.CO;2, 1998.

Otto, S., de Reus, M., Trautmann, T., Thomas, A., Wendisch, M., and Borrmann, S.: Atmospheric radiative effects of an in situ measured Saharan dust plume and the role of large particles, Atmos. Chem. Phys., 7, 4887-4903, https://doi.org/10.5194/acp-74887-2007, 2007.

Philipona, R., Kräuchi, A., and Brocard, E.: Solar and thermal radiation profiles and radiative forcing measured through the atmosphere, Geophys. Res. Lett., 39, L13806, https://doi.org/10.1029/2012GL052087, 2012.

Prata, A.: A new long-wave formula for estimating downward clearsky radiation at the surface, Q. J. Roy. Meteorol. Soc., 122, 11271151, 1996.

Redondas, A. and Cede, A.: Brewer algorithm sensitivity analysis, in: Sauna Workshop, Puerto de la Cruz,Tenerife, Spain, 2006.

Ricchiazzi, P., Yang, S., Gautier, C., and Sowle, D.: SBDART: A research and teaching software tool for plane-parallel radiative transfer in the Earth's atmosphere, B. Am. Meteorol. Soc., 79, 2101-2114, 1998.

Rodgers, C. D.: Inverse methods for atmospheric sounding: theory and practice, in: vol. 2, World Scientific, Singapore, 2000.

Rodriguez-Franco, J. J. and Cuevas, E.: Characteristics of the subtropical tropopause region based on long-term highly resolved sonde records over Tenerife, J. Geophys. Res.-Atmos., 118, 10,754-10,769, https://doi.org/10.1002/jgrd.50839, 2013.

Romero Campos, P. M., Cuevas Agulló, E., Ramos López, R., Valdés Pérez de Vargas, M., and Schneider, M.: Programa de va- 
por de agua en columna del Centro de Investigación Atmosférica de Izaña: Análisis e Intercomparación de diferentes Técnicas de Medida, NIPO 784-09-009-9, Agencia Estatal de Meteorologia, Ministerio de Medio Ambiente, y Medio Rural y Marino, Spain, 2009.

Rothman, L. S., Gordon, I. E., Babikov, Y., Barbe, A., Chris Benner, D., Bernath, P. F., Birk, M., Bizzocchi, L., Boudon, V., Brown, L. R., Campargue, A., Chance, K., Cohen, E. A., Coudert, L. H., Devi, V. M., Drouin, B. J., Fayt, A., Flaud, J.M., Gamache, R. R., Harrison, J. J., Hartmann, J.-M., Hill, C., Hodges, J. T., Jacquemart, D., Jolly, A., Lamouroux, J., Le Roy, R. J., Li, G., Long, D. A., Lyulin, O. M., Mackie, C. J., Massie, S. T., Mikhailenko, S., Müller, H. S. P., Naumenko, O. V., Nikitin, A. V., Orphal, J., Perevalov, V., Perrin, A., Polovtseva, E. R., Richard, C., Smith, M. A. H., Starikova, E., Sung, K., Tashkun, S., Tennyson, J., Toon, G. C., Tyuterev, V. G., and Wagner, G.: The HITRAN2012 molecular spectroscopic database, J. Quant. Spectrosc. Ra., 130, 4-50, https://doi.org/10.1016/j.jqsrt.2013.07.002, 2013.

Ruckstuhl, C., Philipona, R., Morland, J., and Ohmura, A.: Observed relationship between surface specific humidity, integrated water vapor, and longwave downward radiation at different altitudes, J. Geophys. Res.-Atmos., 112, D03302, https://doi.org/10.1029/2006JD007850, 2007.

Scheel, H.: System and Performance Audit for Nitrous Oxide at the Global GAW Station Izaña, Tenerife, Spain, November 2008, WCC-N2O Report 2008/11, http://www.izana.aemet.es (last access: 1 December 2015), 2009.

Schneider, M. and Hase, F.: Technical Note: Recipe for monitoring of total ozone with a precision of around 1 DU applying midinfrared solar absorption spectra, Atmos. Chem. Phys., 8, 63-71, https://doi.org/10.5194/acp-8-63-2008, 2008.

Schneider, M., Blumenstock, T., Chipperfield, M., Hase, F., Kouker, W., Reddmann, T., Ruhnke, R., Cuevas, E., and Fischer, H.: Subtropical trace gas profiles determined by ground-based FTIR spectroscopy at Izaña $\left(28^{\circ} \mathrm{N}, 16^{\circ} \mathrm{W}\right)$ : Five-year record, error analysis, and comparison with 3D CTMs, Atmos. Chem. Phys., 5, 153-167, https://doi.org/10.5194/acp-5-153-2005, 2005.

Schneider, M., Romero, P. M., Hase, F., Blumenstock, T., Cuevas, E., and Ramos, R.: Continuous quality assessment of atmospheric water vapour measurement techniques: FTIR, Cimel, MFRSR, GPS, and Vaisala RS92, Atmos. Meas. Tech., 3, 323338, https://doi.org/10.5194/amt-3-323-2010, 2010.

Schweizer, D. and Gautier, C.: Validation of downwelling longwave computations with surface measurements during FIFE 89, J. Geophys. Res.-Atmos., 100, 11569-11579, 1995.

Shettle, E. P.: Models of aerosols, clouds, and precipitation for atmospheric propagation studies, in: Proceedings of AGARD Conference No. 454, Atmospheric Propagation in the UV, Visible, IR and MM-region and Related System Aspects, Copenhagen, Denmark, 1990.

Stamnes, K., Tsay, S.-C., Wiscombe, W., and Jayaweera, K.: Numerically stable algorithm for discrete-ordinate-method radiative transfer in multiple scattering and emitting layered media, Appl. Optics, 27, 2502-2509, 1988.

Stamnes, K., Tsay, S.-C., Wiscombe, W., and Laszlo, I.: DISORT, a general-purpose Fortran program for discrete-ordinate-method radiative transfer in scattering and emitting layered media: documentation of methodology, Tech. rep., Dept. of Physics and
Engineering Physics, Stevens Institute of Technology, Hoboken, 2000.

Swinbank, W. C.: Long-wave radiation from clear skies, Q. J. Roy. Meteorol. Soc., 89, 339-348, 1963.

Vaisala: Vaisala Radiosonde RS92-SGP, http://www.vaisala.com (last access: 9 June 2018), 2013.

Viúdez-Mora, A., Calbó, J., González, J., and Jiménez, M.: Modeling atmospheric longwave radiation at the surface under cloudless skies, J. Geophys. Res.-Atmos., 114, D18107, https://doi.org/10.1029/2009JD011885, 2009.

Viúdez-Mora, A., Costa-Surós, M., Calbó, J., and González, J. A.: Modeling atmospheric longwave radiation at the surface during overcast skies: The role of cloud base height, J. Geophys. Res.Atmos., 120, 199-214, https://doi.org/10.1002/2014JD022310, 2015.

Wacker, S., Gröbner, J., Emde, C., Vuilleumier, L., Mayer, B., and Rozanov, E.: Comparison of measured and modeled nocturnal clear sky longwave downward radiation at Payerne, Switzerland, AIP Conf. Proc., 1100, 589-592, 2009.

Wacker, S., Gröbner, J., Hocke, K., Kämpfer, N., and Vuilleumier, L.: Trend analysis of surface cloud-free downwelling long-wave radiation from four Swiss sites, J. Geophys. Res.-Atmos., 116, D10104, https://doi.org/10.1029/2010JD015343, 2011.

Wang, K. and Dickinson, R. E.: Global atmospheric downward longwave radiation at the surface from ground-based observations, satellite retrievals, and reanalyses, Rev. Geophys., 51, 150185, 2013.

Wild, M.: Changes in shortwave and longwave radiative fluxes as observed at BSRN sites and simulated with CMIP5 models, AIP Conf. Proc., 1810, 090014, https://doi.org/10.1063/1.4975554, 2017.

Wild, M., Ohmura, A., and Cubasch, U.: GCM-simulated surface energy fluxes in climate change experiments, J. Climate, 10, 3093-3110, https://doi.org/10.1175/15200442(1997)010<3093:GSSEFI>2.0.CO;2, 1997.

Wild, M., Ohmura, A., Gilgen, H., Morcrette, J.-J., and Slingo, A.: Evaluation of downward longwave radiation in general circulation models, J. Climate, 14, 3227-3239, 2001.

Wild, M., Folini, D., Schär, C., Loeb, N., Dutton, E. G., and KönigLanglo, G.: A new diagram of the global energy balance, AIP Conf. Proc., 1531, 628-631, 2013.

Wild, M., Folini, D., Hakuba, M. Z., Schär, C., Seneviratne, S. ., Kato, S., Rutan, D., Ammann, C., Wood, E. F., and KönigLanglo, G.: The energy balance over land and oceans: an assessment based on direct observations and CMIP5 climate models, Clim. Dynam., 44, 3393-3429, 2015.

WMO: Commission for Instruments and Methods of Observation,Sixteenth session, WMO no. 1138, Secretariat of the World Meteorological Organization, Saint Petersburg, 2014a.

WMO: Guide to Meteorological Instruments and Methods of Observation: (CIMO guide), Secretariat of the World Meteorological Organization, Geneva, Switzerland, 2014b.

Zellweger, C., Steinbacher, M., Buchmann, B., and Steinbrecher, R.: System and Performance Audit of Surface Ozone, Methane, Carbon Dioxide, Nitrous Oxide and Carbon Monoxide at the Global GAW Station Izaña, September 2013, WCC-Empa Report 15/4, Institute of Meteorology and Climate Research (IMKIFU), Garmisch-Partenkirchen, Germany, 2015. 